\title{
PENGARUH SUHU PROSES HYDRO THERMAL DEWATERING TERHADAP KARAKTERISTIK COAL WATER MIXTURE
}

\author{
Effect of Hydro Thermal Dewatering Processing Temperature on Coal \\ Water Mixture Characteristics
}

\author{
DATIN F. UMAR ${ }^{*}$ dan LISTON SETIAWAN** \\ Pusat Penelitian dan Pengembangan Teknologi Mineral dan Batubara \\ Jalan Jenderal Sudirman 623 Bandung 40211 \\ Telp. (022)6030483, Fax. (022) 6003373 \\ e-mail: datin.umar@esdm.go.id \\ *Kontributor Utama, **Kontributor Anggota
}

\begin{abstract}
ABSTRAK
Batubara peringkat rendah umumnya mempunyai kadar air bawaan yang tinggi. Sebagai bahan baku pembuatan coal water mixture (CWM), batubara tersebut tidak cocok digunakan sebagai bahan baku karena akan menghasilkan CWM dengan kadar air yang tinggi, sehingga nilai kalor menjadi rendah. Untuk mengurangi kadar air, dilakukan proses hydro thermal dewatering (HTD). Dalam penelitian ini digunakan batubara peringkat rendah yang berasal dari daerah Bayung Lencir, Kab. Musi Banyuasin. Untuk mengetahui pengaruh suhu proses HTD terhadap karaktersitik CWM yang dihasilkan, maka proses HTD dilakukan pada suhu 270,300 dan $330^{\circ} \mathrm{C}$. Hasil penelitian menunjukkan bahwa kadar air bawaan batubara turun dari 30,85\% menjadi 5,95\%, 4,46\% dan 3,64\% (adb) secara berurutan pada suhu proses 270,300 dan $330^{\circ} \mathrm{C}$. Nilai kalor batubara meningkat dari $4.555 \mathrm{kkal} / \mathrm{kg}$ (adb) menjadi $6.331 \mathrm{kkal} / \mathrm{kg}$, $6.539 \mathrm{kkal} / \mathrm{kg}$ dan $6.845 \mathrm{kkal} / \mathrm{kg}(\mathrm{adb})$ masing-amsing pada suhu proses 270, 300 dan $330^{\circ} \mathrm{C}$. CWM yang dibuat dengan menggunakan batubara tanpa melalui proses HTD, kandungan batubara dalam CWM maksimal $43,33 \%$ berat. Setelah proses HTD pada suhu $270^{\circ} \mathrm{C}$, kandungan CWM maksimal $57,07 \%$ berat, pada suhu $300^{\circ} \mathrm{C} 61,28 \%$ berat dan pada suhu $330^{\circ} \mathrm{C} 63,61 \%$ berat dengan viskositas semu pada shear rate 1/100 detik yang hampir sama, yaitu antara 900-1.100 mPa.s.
\end{abstract}

Kata kunci: batubara peringkat rendah, kadar air, nilai kalor, suhu proses, viskositas semu.

\begin{abstract}
Low-rank coals generally have a high inherent moisture content. As a raw material for coal water mixture (CWM) preparation, the coal is not suitable to be used as raw material because it will produce CWM with high water content so that the calorific value is low. To reduce the moisture content, a hydro thermal dewatering (HTD) process was carried out. In this study, low-rank coal used was originated from the Bayung Lencir area, Musi Banyuasin Regency. To study the effect of the HTD process temperature on the characteristics of the CWM, the HTD process was carried out at temperatures of 270,300 , and $330^{\circ} \mathrm{C}$. The results indicated that the moisture content of the coal decreased from $30.85 \%$ to $5.95 \%, 4.46 \%$, and $3.64 \%$ (adb) at the process temperature of 270, 300 , and $330^{\circ} \mathrm{C}$ respectively. The calorific value of coal increased from 4,555 $\left.\mathrm{kcal} / \mathrm{kg} \mathrm{(adb}\right)$ to $6,331 \mathrm{kcal} / \mathrm{kg}, 6,539$ $\mathrm{kcal} / \mathrm{kg}$ and $6,845 \mathrm{kcal} / \mathrm{kg}(\mathrm{adb})$ respectively at a process temperature of 270,300 and $330^{\circ} \mathrm{C}$. CWM prepared using coal without the HTD process, the maximum coal content in CWM is $43.33 \mathrm{wt} \%$. After the HTD process at a temperature of $270^{\circ} \mathrm{C}$, the maximum CWM content is $57.07 w t \%$, at a temperature of $300^{\circ} \mathrm{C} 61.28 w t \%$, and at a temperature of $330^{\circ} \mathrm{C} 63.61 \mathrm{wt} \%$ with a relatively similar apparent viscosity at a shear rate of $1 / 100 \mathrm{sec}$ between 900-1,100 mPa.s.
\end{abstract}

Keywords: apparent viscosity, calorific value, low-rank coal, moisture content, processing temperature. 


\section{PENDAHULUAN}

Coal water mixture (CWM) adalah bahan bakar campuran antara batubara dan air membentuk suspensi kental dan homogen serta stabil selama penyimpanan, pengangkutan dan pembakaran. CWM mempunyai sifat yang sama dengan bahan bakar minyak (BBM) seperti minyak berat, sehingga bisa dialirkan atau dipompa pada saat transportasi maupun pembakaran. Dengan demikian CWM dapat digunakan sebagai bahan bakar pengganti minyak berat pada industri yang biasa menggunakan boiler (Hashimoto, 1999). Dengan adanya pengungkungan/penjebakan batubara di dalam air, bahaya emisi debu dan penyalaan spontan serta peledakan yang biasa terjadi pada batubara serbuk dapat dihindarkan.

Keuntungan penggunaan batubara dalam bentuk CWM antara lain (Hashimoto, 1999; Atesok dkk., 2002; Baranova dkk., 2014; Nyashina, Kuznetsov dan Strizhak, 2018):

- Sifat alirnya yang tergolong bersifat cairan (fluida) sama dengan sifat alir BBM.

- Dapat digunakan langsung sebagai bahan bakar cair menggantikan minyak berat di kilang-kilang minyak atau industri lainnya yang biasa menggunakan minyak bakar berat (heavy fuel oil) sebagai bahan bakar untuk pengolahan produknya.

- Penanganan sama dengan penanganan minyak berat, sehingga memungkinkan pengiriman/pengangkutan CWM di antara berbagai lokasi di dalam/luar instalasi/ pabrik lewat pipa.

- Dapat menggunakan boiler yang sama dengan boiler yang biasa digunakan untuk minyak berat dengan melakukan sedikit modifikasi

- Batubara dalam bentuk suspensi dapat ditangani secara lebih bersih hingga menunjang program bersih lingkungan dan terhindar dari kemungkinan terjadinya pembakaran spontan, peledakan dan masalah debu yang biasa ditimbulkan batubara dalam bentuk serbuk.

Batubara dalam CWM mempunyai kecenderungan untuk memisah dengan air karena mempunyai berat jenis yang lebih besar daripada berat jenis air. Untuk menjaga agar batubara tetap terdispersi dengan baik membentuk suspensi yang homogen dan stabil, maka diperlukan zar aditif yang pada umumnya berupa bahan kimia yang mempunyai pengaruh terhadap penurunan tegangan permukaan (surfaktan). Biasanya bahan aditif ini berupa bahan organik yang mempunyai gugusan $-\mathrm{N}$ $\mathrm{CH}_{2}-\mathrm{CH}_{2}$ - O-. Penambahan surfaktan menyebabkan terjadinya penurunan tegangan permukaan dan keseimbangan termodinamik dapat didekati, walaupun tidak sampai mencapai angka nol dan suspensi masih mempunyai kecenderungan untuk menggumpal. Oleh karena itu, bahan aditif ini selain sebagai surfaktan juga harus sebagai penyebar (dispersant) dan pensuspensi (suspending agent) untuk mempertahankan partikel yang cenderung menggumpal tersebut tetap tersebar dengan baik dalam suspensi (Xiaochun, Guoguang and Gongyuan, 2004; Yuchi $d k k ., 2005$; Li $d k k ., 2008$; Routray $d k k .$, 2019; Das dkk., 2020).

Batubara sebagai bahan baku pembuatan CWM sebaiknya batubara bituminus dengan kadar air bawaan yang relatif rendah $(<10 \%)$. Karena batubara dengan kadar air yang tinggi (lignit dan sub-bituminus) biasanya bersifat hidrofilik, yaitu sifat menyukai air sehingga air yang diperlukan untuk pembuatan CWM lebih besar. Dengan tingginya kadar air dalam CWM, maka viskositas CWM menjadi rendah sehingga kestabilan menurun. Selain itu, nilai kalor CWM juga menjadi semakin rendah. Oleh sebab itu sebagai bahan baku pembuatan CWM, batubara peringkat rendah perlu melalui proses upgrading terlebih dahulu (Umar dkk., 2007; Yu, Liu and Cen, 2014; Liu $d k k ., 2016)$. Dengan proses upgrading, kadar air dalam batubara tersebut menjadi turun sehingga menghasilkan CWM dengan kandungan batubara yang cukup tinggi.

Beberapa teknologi upgrading batubara untuk menurunkan kadar air telah diperkenalkan dan dikembangkan, di antaranya adalah hydro thermal dewatering (HTD). Batubara yang dipanaskan pada suhu $>250^{\circ} \mathrm{C}$ dan tekanan $>50$ atm, menyebabkan terjadinya perubahan komposisi struktur batubara, yaitu keluarnya air bawaan (inherent moisture), dekomposisi gugus karboksil, penyusutan gas-gas hidrogen dan oksigen kompleks serta aromatisasi (Ge $d k k .$, 2015; Wu dkk., 2015; Liao dkk., 2016).

Tujuan utama penelitian ini adalah untuk mengetahui pengaruh suhu pemanasan pada 
proses HTD terhadap karakteristik CWM, yaitu jumlah/kandungan batubara, nilai kalor dan sifat alir/rheology. Menurut Mishra, Senapati dan Panda (2002); Boylu, Dinçer dan Ateşok (2004) dan Ongsirimongkol dan Narasingha (2012), CWM yang akan digunakan sebagai bahan bakar harus mengikuti persayaratan sebagai berikut:

- Mempunyai jumlah/kandungan batubara dalam CWM yang tinggi dengan viskositas semu pada shear rate 1/100 detik antara 900-1.100 mPa.s.

- Mempunyai nilai yield stress optimum hingga dihasilkan CWM dengan kestabilan yang baik, baik dalam keadaan statis maupun dinamis.

- Mempunyai sifat aliran seperti fluida Newtonian saat diberikan shear rate dengan pemompaan pada waktu pengangkutan melalui pipa ataupun waktu pembakaran.

- Mempunyai viskositas yang tinggi saat penyimpanan, viskositas sedang pada saat pengangkutan dan viskositas rendah saat pembakaran.

\section{METODE}

Batubara yang digunakan dalam penelitian ini adalah batubara peringkat rendah yang berasal dari daerah Bayung Lencir, Kab Musi Banyuasin, Sumatera Selatan. Kualitas batubara di daerah ini; air total $43,0-51,7 \%$ (as received); air bawaan $14,0-18,6 \%$, zat terbang $38,2-45,9 \%$, karbon padat $26,0-35,9 \%$, abu $5,6-12,9 \%$, total sulfur $0,28-2,21 \%$, specific gravity 1.36 - 1.51; dan nilai kalor $4.040-$ $5.275 \mathrm{kal} / \mathrm{g}$ (Air dried basis). Menurut klasifikasi ASTM batubara tersebut termasuk klas Sub-bituminus, grup batubara Subbituminus B hingga batubara Sub-bituminus A (Sukardi dan Suryana, 1999).

Sampel batubara dikeringkan di udara terbuka pada suhu kamar. Peremukan pertama dilakukan dengan menggunakan jaw crusher kemudian hammer mill. Sampel kemudian dibagi dua untuk analisis kimia batubara dan untuk proses upgrading. Sampel batubara untuk analisis kimia digiling dengan menggunakan coffee mill sampai berukuran 60 mesh (ASTM D 2013/2013 M), sedangkan untuk upgrading dan pembuatan CWM, 70\% lolos saringan 150 mesh $(<100 \mu \mathrm{m})$.
Analisis yang dilakukan meliputi analisis proksimat yang terdiri atas: air total dalam as received (ar) air bawaan (inherent moisture) menurut ASTM D 3176, , abu ASTM D 3175, zat terbang (volatile matter) menurut ASTM D 3175 dan karbon padat (fixed carbon) berdasarkan perhitungan $100 \%$ - \%(air bawaan +abu+zat terbang) dalam air dried basis (adb), Analisis ultimat terdiri atas: karbon $(C)$, hidrogen $(\mathrm{H})$, menurut ASTM D 3179-89, nitrogen $(\mathrm{N})$ menurut ASTM D 3179, total sulfur (S) dengan metoda infra red, dan oksigen (O) berdasarkan perhitungan 100\%$\%(\mathrm{C}+\mathrm{H}+\mathrm{N}+\mathrm{S}+\mathrm{abu})$ dan nilai kalor menurut standar ASTM 5865-04, kal/g dalam adb.

Proses upgrading dilakukan dengan variabel suhu yaitu 270,300 , dan $330^{\circ} \mathrm{C}$ masing-masing pada tekanan 60, 90 dan 125 Bar dengan menggunakan autoklaf. Batubara dicampur dengan air (persen padatan $\pm 30 \%$ ) jumlah total sekitar \pm 2.500 gram dimasukkan ke dalam autoklaf kapasitas 10 L. Autoklaf dipanaskan sampai temperatur yang diinginkan tercapai dan biarkan pada temperatur tersebut selama 30 menit (Umar, Shimojo dan Madioutomo, 2018), kemudian didinginkan. Setelah dingin batubara yang telah diproses dikeluarkan dari autoklaf. Batubara hasil proses tersebut kemudian dibagi dua, sebagian untuk analisis kimia dan sebagian lagi untuk dibuat CWM.

Batubara hasil proses upgrading untuk analisis dikeringkan sampai beratnya tetap, kemudian dianalisis terhadap proksimat, ultimat dan nilai kalor. Batubara hasil proses upgrading untuk pembuatan CWM, langsung dibuat CWM dengan memerhatikan persen padatan (batubara) dan berat campuran batubara dan air pascaproses. Zat aditif NSF $\mathrm{H}-21$ ditambahkan sebagai dispersan sebanyak $0,3 \%$ berat batubara dan penstabil atapul D-150 sebanyak $1,0 \mathrm{mg} / \mathrm{kg}$ CWM. Selanjutnya diaduk sampai homogen menggunakan laboratory blender pada kecepatan pengaduk $12.000-$ $13.000 \mathrm{rpm}$.

CWM yang didapat kemudian diuji sifat alirnya menggunakan viskometer Haake RheoWin 4 pada berbagai jumlah/kandungan batubara hingga dicapai CWM dengan viskositas semu pada shear rate 1/100 detik antara 900-1100 $\mathrm{mPa} \cdot \mathrm{s}$. Secara skematis, penelitian proses pembuatan CWM melalui proses HTD dapat dilhat pada Gambar 1. 


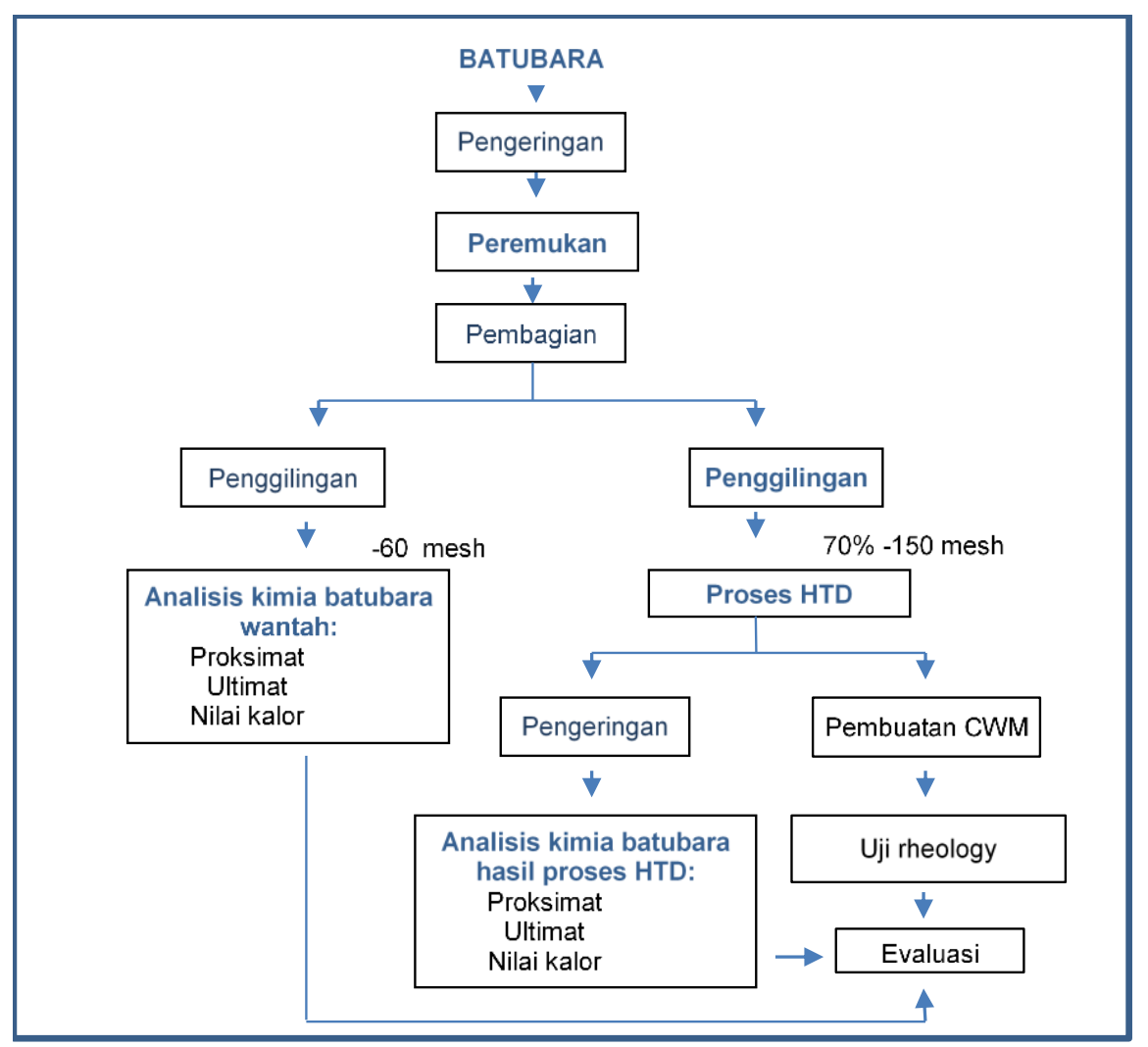

Gambar 1. Skema penelitian pembuatan CWM melalui proses HTD

\section{HASIL DAN PEMBAHASAN}

Hasil analisis batubara sebelum dan setelah proses HTD pada berbagai suhu dapat dilihat pada Tabel 1. Tabel 1 menunjukkan bahwa sampel batubara mempunyai kadar air bawaan yang cukup tinggi yaitu 30,85\% (adb) dengan nilai kalor $4.555 \mathrm{kal} / \mathrm{g}$ dalam adb atau 6.587 $\mathrm{kal} / \mathrm{g}$ dalam db. Menurut Yu, Liu dan Cen (2014) dan Zhu dkk. (2014), sebagai bahan baku pembuatan CWM batubara dengan kadar air yang tinggi $(>10 \%)$ akan menghasilkan CWM dengan persen padatan yang rendah sehingga nilai kalor CWM tersebut menjadi rendah pula (Mishra dan Kanungo, 2000).

Tabel 1. Hasil analisis sampel batubara

\begin{tabular}{lcccc}
\hline \multicolumn{1}{c}{ Analisis } & Batubara wantah & HTD 270 ${ }^{\circ} \mathrm{C}$ & $\mathrm{HTD} \mathrm{300}{ }^{\circ} \mathrm{C}$ & $\mathrm{HTD} 330^{\circ} \mathrm{C}$ \\
\hline Air bawaan, \% adb & 30,85 & 5,95 & 4,46 & 3,64 \\
Abu, \% db & 4,01 & 4,97 & 4,90 & 5,35 \\
Zat terbang, \% db & 52,96 & 47,90 & 43,79 & 42,51 \\
Karbon padat, \% db & 43,04 & 47,13 & 51,31 & 52,14 \\
Karbon, \% db & 70,60 & 68,77 & 70,39 & 73,26 \\
Hidrogen, \% db & 5,75 & 4,66 & 4,60 & 4,51 \\
Nitrogen, \% db & 1,85 & 1,29 & 1,28 & 1,27 \\
Sulfur total, \% db & 3,05 & 2,65 & 2,87 & 2,92 \\
Oksigen, \% db & 14,74 & 17,67 & 15,97 & 12,70 \\
Nilai kalor, kcal/kg db & 6587 & 6732 & 6844 & 7104 \\
Nilai kalor, kcal/kg adb & 4.555 & 6.331 & 6.539 & 6.845 \\
O/C & 0,21 & 0,26 & 0,23 & 0,17 \\
\hline
\end{tabular}

Catatan: Adb: air dried basis, dasar kering udara Db: dry basis: dasar kering 
Sifat fisik CWM berupa suspensi dan tidak dapat dibakar secara langsung. Cara pembakaran CWM adalah dengan cara injeksi ke dalam tungku yang sebelumnya telah dipanaskan. Secara umum, proses pembakaran meliputi 2 (dua) tahap, yaitu tahap penguapan air dan tahap pembakaran (Burdukov $d k k$., 2002).

- Tahap penguapan air

Peristiwa pertama yang terjadi ketika CWM disemprotkan ke tungku pembakar, adalah peristiwa penguapan air. Selama proses ini batubara belum terbakar, proses pembakaran tertunda dan dapat menurunkan suhu tungku. Oleh karena itu, makin cepat waktu penguapan air, makin sempurna pembakaran CWM (Valiullin $d k k ., 2020)$.

CWM dengan kadar air yang tinggi, untuk menguapkan air membutuhkan energi yang lebih besar dibandingkan dengan CWM dengan kadar air yang rendah. Begitu pula waktu penguapan akan semakin lama (Pinchuk, Sharabura dan Kuzmin, 2019). Akibat adanya proses penguapan air ini maka ruang pembakaran suhunya menjadi rendah. Selain itu, nilai kalor CWM juga harus dapat mencukupi energi yang diperlukan untuk proses penguapan air tersebut.

- Tahap pembakaran

Setelah air yang terdapat dalam CWM menguap, tahap berikutnya adalah tahap pembakaran. Pada pembakaran CWM, reaksi antara karbon dan hidrogen yang ada dalam batubara dengan oksigen dari udara menghasilkan karbon dioksida dan uap air serta panas. Makin tinggi kadar karbon dalam CWM, pembakaran akan makin lebih baik dan efisiensi pembakaran akan menjadi lebih tinggi dibandingkan dengan CWM yang mempunyai kandungan karbon yang lebih rendah.

Jumlah oksigen yang diperlukan dalam pembakaran tersebut secara teoritis dapat dihitung dan disebut dengan kebutuhan stoikiometri. Pada kenyataannya karena proses pembakaran tidak mencapai keadaan ideal, diperlukan $\mathrm{O}_{2}$ yang berlebih, yaitu udara yang dikonsumsi lebih besar dari kebutuhan teoritis. Oksigen yang berlebih ini disebut dengan excess air. Jika jumlah $\mathrm{O}_{2}$ yang diperlukan tidak mencukupi, maka reaksi antara karbon dan oksigen akan membentuk gas $\mathrm{CO}$ (Salomatov dkk., 2016).

Proses HTD cukup efektif menurunkan kadar air dalam batubara secara signifikan. Makin tinggi suhu proses, makin rendah kadar air batubara tersebut. Batubara sebelum proses mempunyai kadar air bawaan 30,85\% turun menjadi 5,95\% setelah proses HTD dengan pemanasan pada suhu $270^{\circ} \mathrm{C}$, menjadi $4,46 \%$ pada suhu $300^{\circ} \mathrm{C}$ dan menjadi 3,64\% (adb) pada pemanasan $330^{\circ} \mathrm{C}$. CWM yang dibuat dari batubara dengan kadar air rendah $(<10 \%)$ dan nilai kalor yang tinggi, diharapkan dapat lebih mudah untuk dibakar dengan nyala api yang stabil dan efisiensi pembakaran yang tinggi.

Berdasarkan penelitian yang telah dilakukan oleh Liao dkk. (2016), proses HTD pada suhu $>290^{\circ} \mathrm{C}$ menunjukkan hasil yang cukup signifikan terhadap penurunan kadar air dan peningkatan nilai kalor. Makin tinggi suhu proses, makin tinggi penurunan kadar air sampai suhu $360^{\circ} \mathrm{C}$.

Derajat pengeringan (degree of dewatering) akibat proses HTD bisa dihitung dengan menggunakan rumus (Favas dan Jackson, 2003):

$\mathrm{DP}=\frac{\text { IM sebelum HTD-IM setelah HTD }}{I M \text { sebelum HTD }} \times 100$

DP: derajat pengeringan

IM: kadar air bawaan, \%

Makin tinggi suhu proses, makin tinggi derajat pengeringan. Pada suhu proses HTD 270, 300 dan $330^{\circ} \mathrm{C}$, derajat pengeringan masingmasing 80,71\%, 85,54\% dan 88,20\%. Dengan turunnya kadar air, maka karbon padat batubara setelah proses HTD meningkat.

Peningkatan kadar abu dry basis (db) dari 4,01 $\%$ menjadi $4,97 \%$ pada pemanasan $270{ }^{\circ} \mathrm{C}$, $4,90 \%$ pada pemanasan $300^{\circ} \mathrm{C}$ dan $5,35 \%$ (db) pada pemanasan $330^{\circ} \mathrm{C}$ tidak begitu berpengaruh terhadap pembakaran CWM, karena CWM yang baik mempunyai kandungan abu < 8\% (Valiullin $d k k$., 2020).

Nilai kalor batubara hasil proses HTD meningkat karena turunnya kadar air dan 
naiknya karbon padat. Batubara sebelum proses mempunyai nilai kalor $4.555 \mathrm{kal} / \mathrm{g}(\mathrm{adb})$ naik menjadi $6.331 \mathrm{kal} / \mathrm{g}(\mathrm{adb})$ pada suhu $270^{\circ} \mathrm{C}$, menjadi $6.539 \mathrm{kal} / \mathrm{g}$ dan $6.845 \mathrm{kal} / \mathrm{g}$ (adb) masing-masing pada suhu $300^{\circ} \mathrm{C}$ dan $330^{\circ} \mathrm{C}$. Berdasarkan klasifikasi yang diterapkan dalam royalti penjualan batubara di Indonesia (PP 45/2003 tentang tarif atas jenis PNBP pada KESDM), batubara sebelum proses termasuk ke dalam batubara kalori rendah $(<5.100 \mathrm{kal} / \mathrm{g}$, $\mathrm{adb})$ dan setelah proses termasuk ke dalam batubara kalori tinggi $(6.100-7.100 \mathrm{kal} / \mathrm{g}$, adb).

Peningkatan nilai kalor batubara, juga meningkatkan nilai kalor CWM sehingga pada saat pembakaran CWM, proses penguapan air akan lebih cepat dan proses pembakaran akan lebih baik dibandingkan dengan CWM yang mempunyai nilai kalor yang rendah. Makin baik proses pembakaran, makin tinggi efisiensi pembakaran sehingga emisi akibat pembakaran batubara akan menjadi berkurang (Nyashina, Kuznetsov dan Strizhak, 2018).

Kadar karbon dalam batubara hasil proses HTD pada suhu 270 dan $300^{\circ} \mathrm{C}$ sedikit turun, yaitu dari $70,60 \%(\mathrm{db})$ masing-masing menjadi $68,77 \%$ dan $70,39 \%$ (db) dan baru meningkat pada suhu $330^{\circ} \mathrm{C}$. Hal ini terjadi karena pemanasan batubara pada suhu antara 200 $300^{\circ} \mathrm{C}$ terjadi reaksi eksotermis karena ikutnya panas pada saat pelepasan air sisa/terikat secara kimia (chemical combined water), oksida karbon dan hidrogen. Pada kondisi ini kadar karbon dan hidrogen dalam batubara akan sedikit menurun (Ullah $d k k$., 2018). Reaksi esterifikasi karena dekomposisi panas baru terjadi pada suhu $>300^{\circ} \mathrm{C}$. Pada suhu ini, batubara mempunyai kecenderungan untuk mengembang yang ditandai dengan terjadinya penguapan zat terbang dan terbentuknya tar batubara sehingga karbon dalam batubara meningkat (Liao dkk., 2016). Kadar hidrogen (db, tanpa moisture) dalam batubara setelah proses HTD turun. Hasil ini sesuai dengan hasil penelitian yang telah dilakukan sebelumnya (Umar, Shimojo dan Madiutomo, 2018) dan penelitian yang dilakukan oleh $\mathrm{Wu} d k k$. (2015). CWM sebagai bahan bakar dengan kadar air yang rendah akan mempercepat proses penguapan air dan kadar karbon yang tinggi, akan mempercepat proses pembakaran.

Sampel batubara yang digunakan untuk penelitian mempunyai kandungan sulfur yang tinggi $(3,05 \%$ db). Setelah proses HTD mengalami sedikit penurunan masing-masing menjadi $2,65 \% ; 2,87 \%$ dan $2,92 \%$ db pada suhu proses 270,300 dan $330^{\circ} \mathrm{C}$. Hal ini sesuai dengan penelitian yang telah dilakukan oleh Sato dkk. (2007) bahwa proses HTD mampu menurunkan kadar sulfur dalam batubara.

Kadar nitrogen setelah proses turun secara signifikan. Suhu relatif tidak berpengaruh terhadap kadar nitrogen. Hasil ini sesuai dengan hasil penelitian yang telah dilakukan oleh Ullah dkk. (2018). Penurunan nitrogen terjadi karena adanya pelarutan atau penguraian mineral dan senyawa yang ada dalam batubara dengan bantuan air (limbah) proses yang bersifat asam karena proses HTD (Liao $d k k ., 2016)$.

Proses HTD pada suhu 270 dan $300^{\circ} \mathrm{C}$, kadar oksigen dalam dry basis mengalami peningkatan dari $14,74 \%$ menjadi $17,67 \%$ dan $15,97 \% \mathrm{db}$, sedangkan pada suhu $330^{\circ} \mathrm{C}$ turun menjadi 12,70\% db. Menurut Liao, dkk., 2016 proses HTD baru memberikan hasil yang optimal jika dipanaskan pada suhu $>300^{\circ} \mathrm{C}$. Peningkatan oksigen yang terjadi pada pemanasan 270 dan $300^{\circ} \mathrm{C}$ kemungkinan disebabkan karena terjadinya oksidasi (reaksi dengan oksigen dari udara) pada mineral/senyawa yang masih terikat dengan kuat pada batubara atau belum terjadi penguraian (Wu dkk., 2015).

CWM merupakan suspensi antara batubara dengan air. Oleh karena itu, sifat permukaan batubara terhadap air mempunyai pengaruh yang sangat besar. Selain unsur karbon, pada permukaan batubara terdapat pula mineral, gugus fungsional dan hidrokarbon. Bagianbagian ini memengaruhi sifat permukaan batubara apakah hidrofilik (sifat menyenangi air) atau hidrofobik (sifat tidak menyenangi air). Sifat-sifat ini memegang peranan penting karena berkaitan dengan wetting ability atau kemampuan terbasahinya batubara oleh air. Batubara peringkat rendah umumnya mempunyai perbandingan $\mathrm{O} / \mathrm{C}$ yang besar dengan sifat permukaan cenderung hidrofilik (Zhang $d k k .$, 2016). Dalam pembuatan CWM sifat hidrofilik ini kurang disenangi karena CWM yang dihasilkan dari batubara jenis ini akan mempunyai kandungan air yang cukup tinggi karena sebagian besar air akan masuk 
terserap oleh batubara. Batubara sebelum proses mempunyai perbandingan $\mathrm{O} / \mathrm{C}$ sebesar 0,21 naik menjadi 0,26 dan 0,23 pada suhu 270 dan $300^{\circ} \mathrm{C}$ lalu turun menjadi 0,17 pada suhu $330^{\circ} \mathrm{C}$. Hal ini menunjukkan bahwa proses HTD efektif untuk menurunkan kadar oksigen dan perbandingan $\mathrm{O} / \mathrm{C}$ pada suhu $>300^{\circ} \mathrm{C}$. Penurunan perbandingan $\mathrm{O} / \mathrm{C}$ diharapkan dapat mengubah sifat permukaan batubara yang hidrofilik menjadi hidrofobik, sehingga CWM yang dibuat dari batubara hasil proses HTD akan mempunyai kandungan batubara yang tinggi, yaitu $>60 \%$ dan air yang rendah, yaitu <40\% (Yu $d k k$., 2012).

Jumlah/kandungan batubara dalam CWM sangat berpengaruh terhadap kualitas CWM. Semakin tinggi kandungan batubara dalam CWM, akan semakin tinggi pula nilai kalor CWM tersebut. CWM dengan nilai kalor yang tinggi akan lebih mudah dibakar dibandingkan dengan CWM yang mempunyai nilai kalor yang rendah. Namun, jumlah batubara dalam CWM akan mencapai suatu titik optimal karena CWM harus mempunyai sifat alir yang baik hingga dapat dialirkan melalui pipa, baik saat transportasi maupun saat pembakaran (Gürses dkk., 2006).

Sifat alir CWM dapat diketahui dari hasil uji rheologi/sifat alir. Hasil pengujian menunjukkan hubungan antara viskositas (n) dengan kecepatan geser dan hubungan antara tegangan geser $(\boldsymbol{r})$ dan kecepatan geser $(\boldsymbol{\gamma})$ yang menunjukkan karakteristik aliran suatu fluida. Secara umum fluida dibagi menjadi 2 kelompok, yaitu (George dan Qureshi, 2013):

- Fluida Newtonian yang mengikuti hukum Newton, yaitu fluida yang mempunyai viskositas yang tetap untuk perubahan kecepatan geser.

- Fluida non-Newtonoian yang tidak mengikuti hukum Newton karena fluida tersebut mempunyai viskositas yang berubah-ubah tergantung pada kecepatan geser.

Fluida non Newtonian terbagai lagi menjadi 3 bagian, yaitu Bingham plastis, pseudoplastis dan dilatan. Kurva aliran Bingham plastis tidak melewati titik awal sumbu tegangan geser tetapi memotong. Jika kurva di interpolasi dari bagiannya yang lurus ke sumbu tegangan geser pada suatu titik sumbu tegangan geser, maka jarak antara titik nol ke titik tersebut disebut dengan yield stress. Hal ini terjadi karena adanya kontak antara partikel yang berdekatan yang harus dipecahkan sebelum fluida tersebut mengalir. Nilai yield stress ini merupakan petunjuk besarnya gaya flokulasi.

Aliran pseudoplastis tidak mempunyai nilai yield stress sebagaimana aliran Bingham plastis. Kurva aliran pseudo plastis mempunyai penurunan slope dengan naiknya kecepatan geser sampai suatu batas slope. Harga viskositas dari aliran fluida Bingham dan pseudo plastis turun dengan naiknya kecepatan geser. Untuk jenis ini disebut shear thinning. Fluida dilatan sebaliknya, harga viskositas naik dengan naiknya kecepatan geser dan disebut dengan shear thickening. Jenis fluida dilatan tidak dikehendaki dalam CWM karena akan menyulitkan jika CWM tersebut dialirkan. CWM yang akan digunakan sebagai bahan bakar sebaiknya mempunyai viskositas yang tinggi saat penyimpanan, yaitu saat diberikan shear rate rendah, viskositas sedang pada saat pengangkutan pada shear rate sedang dan viskositas rendah saat pembakaran, yaitu ketika diberikan shear rate yang tinggi (Turian, 2002). Hasil pengujian sifat alir CWM dari batubara hasil proses upgrading dengan proses HTD pada suhu 270,300 dan $330^{\circ} \mathrm{C}$ dapat dilihat pada Gambar 2 sampai 5.

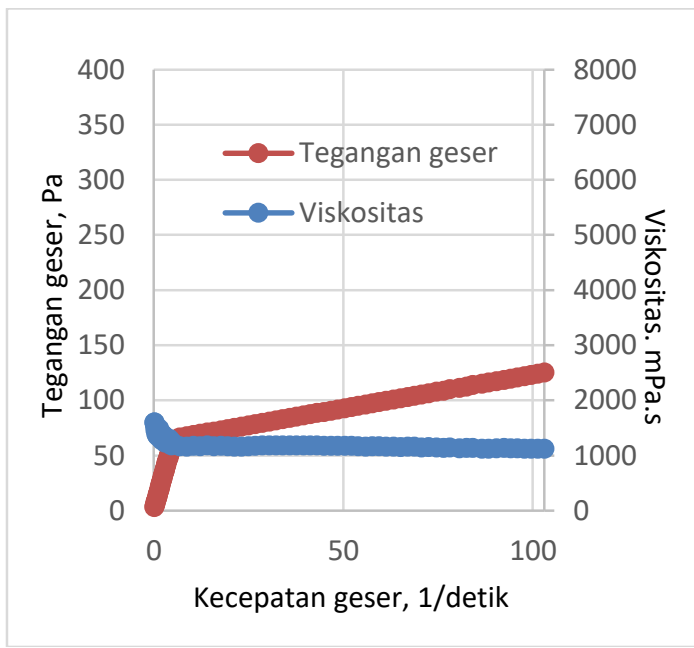

Gambar 2. Sifat alir CWM dari batubara tanpa proses HTD 


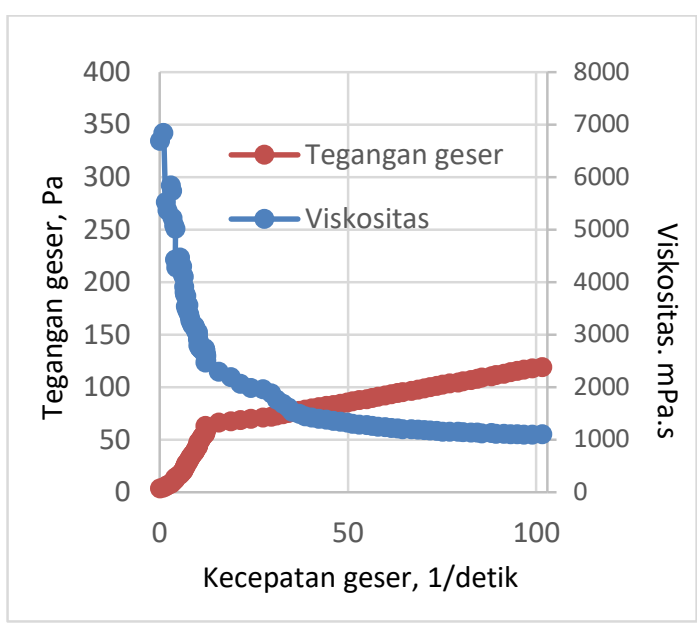

Gambar 3. Sifat alir CWM dari batubara hasil proses $\mathrm{HTD}$ suhu $270^{\circ} \mathrm{C}$

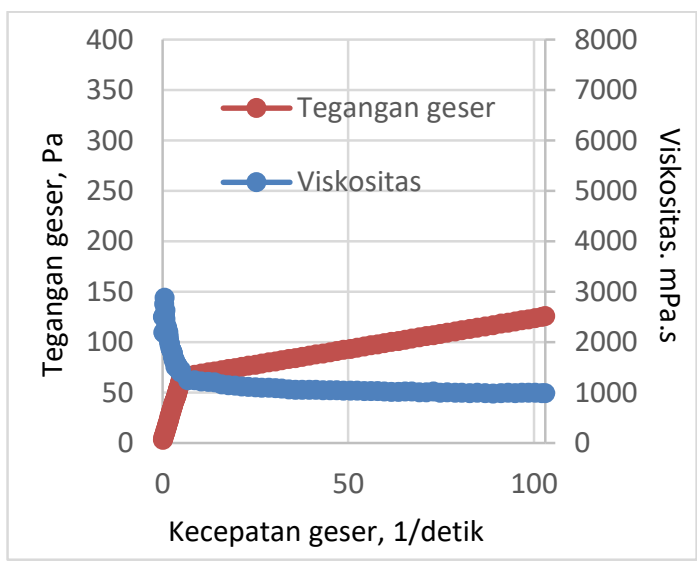

Gambar 4. Sifat alir CWM dari batubara hasil proses HTD suhu $300^{\circ} \mathrm{C}$

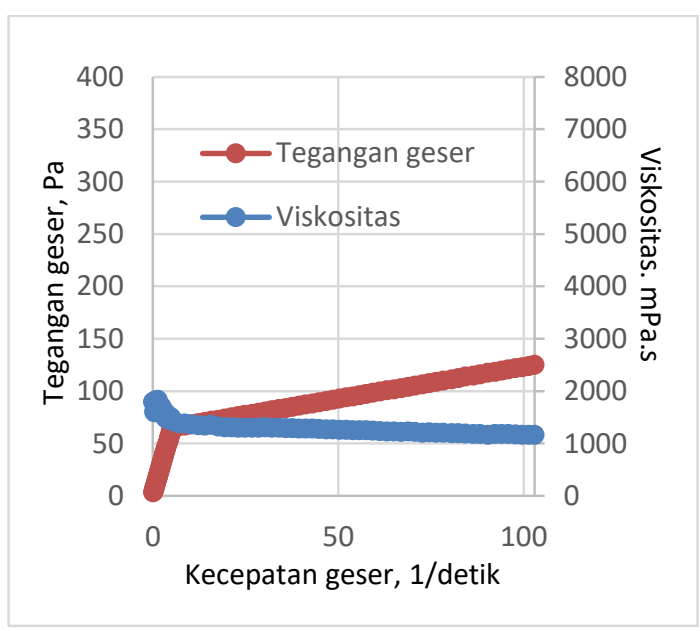

Gambar 5. Sifat alir CWM dari batubara hasil proses $\mathrm{HTD}$ suhu $330^{\circ} \mathrm{C}$
Gambar 2 sampai 5 menunjukkan bahwa CWM dengan menggunakan batubara tanpa proses HTD dan hasil proses HTD pada suhu 270,300 dan $330^{\circ} \mathrm{C}$ mempunyai sifat fluida yang non-Newtonion, yaitu viskositas berubah dengan berubahnya kecepatan geser.

Viskositas turun dengan naiknya kecepatan geser dan tidak mempunyai yield stress, yang menunjukkan bahwa CWM tersebut mempunyai sifat alir non-Newtonian pseudoplastis. Tegangan geser naik dengan naiknya kecepatan geser. Hasil ini menunjukkan bahwa CWM yang dihasilkan mempunyai sifat alir yang baik karena mempunyai viskositas yang tinggi pada kecepatan geser rendah, viskositas sedang pada kecepatan geser sedang dan viskositas rendah pada kecepatan geser tinggi. Hal ini sesuai dengan hasil penelitian yang telah dilakukan oleh Gürses dkk. (2006).

Pada kecepatan geser tinggi, aliran CWM menyerupai sifat aliran fluida Newtonian, yaitu viskositas relatif tetap dengan naiknya kecepatan geser sehingga akan memudahkan saat CWM tersebut ditransportasikan dan dibakar dengan bantuan pompa. Kandungan batubara dan viskositas semu pada kecepatan geser 1/100 detik dapat dilihat pada Tabel 2 .

CWM yang dibuat dari batubara peringkat rendah tanpa melalui proses HTD, konsentrasi batubara hanya mencapai $43,33 \%$. Semakin tinggi suhu proses HTD, semakin tinggi konsentrasi batubara dalam CWM pada viskostas semu 1/100 detik sesuai target, yaitu pada kisaran 900-1100 mPas.

Nilai kalor CWM tanpa melalui proses HTD sangat rendah, yaitu $1.974 \mathrm{kkal} / \mathrm{kg}$, sedangkan CWM yang dibuat dengan batubara hasil proses HTD, nilai kalor meningkat seiring dengan meningkatnya konsentrasi batubara dan suhu proses. Hasil ini menunjukkan bahwa proses HTD efektif untuk meningkatkan konsentrasi batubara dan nilai kalor CWM. Hasil ini sesuai dengan hasil penelitian yang telah dilakukan oleh Yu dkk. (2012). 
Tabel 2. Karakteritik CWM

\begin{tabular}{lcccc}
\hline & Raw & HTD $270^{\circ} \mathrm{C}$ & $\mathrm{HTD} 300^{\circ} \mathrm{C}$ & $\mathrm{HTD} \mathrm{330} 0^{\circ} \mathrm{C}$ \\
\hline Batubara, \% berat & 43,33 & 57,07 & 61,28 & 63,61 \\
Viskositas semu pada 1/detik, mPas & 977,79 & 1049,3 & 940,42 & 1094,7 \\
Nilai kalor kal/g & 1.974 & 3.613 & 4.007 & 4.354 \\
\hline
\end{tabular}

\section{KESIMPULAN DAN SARAN}

\section{Kesimpulan}

Proses HTD efektif menurunkan kadar air dalam batubara peringkat rendah sehingga nilai kalor meningkat. Dengan proses HTD, klasifikasi batubara dari batubara nilai kalor rendah $(<5.100 \mathrm{kal} / \mathrm{g}$, adb) naik menjadi batubara nilai kalor tinggi (6.100-7.100 kal/g, adb).

Suhu proses HTD sangat berpengaruh terhadap penurunan kadar air dan peningkatan nilai kalor. Suhu di atas $>300^{\circ} \mathrm{C}$, mampu menurunkan kadar oksigen dalam batubara, sehinga perbandingan $\mathrm{O} / \mathrm{C}$ juga turun yang menunjukkan terjadinya perubahan sifat permukaan dari hidrofilik menjadi horofobik.

Proses HTD meningkatkan jumlah/konsentrasi batubara dalam CWM. Semakin tinggi suhu proses HTD, semakin tinggi konsentrasi batubara dalam CWM dengan viskositas semu yang hampir sama $( \pm 1.000 \mathrm{mPa} \cdot \mathrm{s})$.

\section{Saran}

Untuk mendapatkan hasil yang lebih optimal, sebaiknya suhu proses HTD $>350^{\circ} \mathrm{C}$ dengan menggunakan autoklaf yang mempunyai presisi yang baik. Secara teknis, proses upgrading dengan HTD bisa diterapkan untuk mendapatkan CWM dengan kualitas yang baik. Untuk mengetahui keekonomiannya, perlu dilakukan kajian lebih lanjut agar teknologi ini bisa dicoba pada skala yang lebih besar supaya bisa segera diterapkan pada skala komersial.

\section{UCAPAN TERIMA KASIH}

Penulis menyampaikan terima kasih yang sebesar-besarnya kepada kepala Puslitbang Teknologi Mineral dan Batubara (tekMIRA) atas terlaksananya penelitian ini. Penulis juga menyampaikan terima kasih kepada rekanrekan di laboratorium batubara yang telah membantu sehingga penelitian ini berjalan dengan baik dan lancar.

\section{DAFTAR PUSTAKA}

Atesok, G., Boylu, F., Sirkeci, A. A. dan Dincer, H. (2002) "The effect of coal properties on the viscosity of coal-water slurries," Fuel, 81(14), hal. 1855-1858. doi: 10.1016/S00162361(02)00107-2.

Baranova, M. P., Li, Q., Zheng, Z.-Y., Li, F.-C., Kulagin, V. A. dan Likhachev, D. S. (2014) "Utilization slurry coal-water fuel," Journal of Siberian Federal University. Engineering \& Technologies, 7(4), hal. 474-479.

Boylu, F., Dinçer, H. dan Ateşok, G. (2004) "Effect of coal particle size distribution, volume fraction and rank on the rheology of coalwater slurries," Fuel Processing Technology, 85(4), hal. 241-250. doi: 10.1016/S03783820(03)00198-X.

Burdukov, A. P., Popov, V. I., Tomilov, V. G. dan Fedosenko, V. D. (2002) "The rheodynamics and combustion of coal-water mixtures," Fuel, 81(7), hal. 927-933. doi: 10.1016/S00162361(01)00009-6.

Das, D., Mohapatra, R. K., Belbsir, H., Routray, A., Parhi, P. K. dan El-Hami, K. (2020) "Combined effect of natural dispersant and a stabilizer in formulation of high concentration coal water slurry: Experimental and rheological modeling," Journal of Molecular Liquids, 320, hal. 114441. doi: 10.1016/j.molliq.2020.114441.

Favas, G. dan Jackson, W. R. (2003) "Hydrothermal dewatering of lower rank coals. 1. Effects of process conditions on the properties of dried product," Fuel, 82(1), hal. 53-57. doi: 10.1016/S0016-2361(02)00192-8.

Ge, L., Zhang, Y., Xu, C., Wang, Z., Zhou, J. dan Cen, K. (2015) "Influence of the hydrothermal dewatering on the combustion characteristics of Chinese low-rank coals," Applied Thermal Engineering, 90, hal. 174-181. doi: 10.1016/j.applthermaleng.2015.07.015. 
George, H. F. dan Qureshi, F. (2013) “Newton's law of viscosity, newtonian and non-newtonian fluids," in Encyclopedia of Tribology. Boston, MA: Springer US, hal. 2416-2420. doi: 10.1007/978-0-387-92897-5_143.

Gürses, A., Açıkyıldız, M., Doğar, Ç., Karaca, S. dan Bayrak, R. (2006) "An investigation on effects of various parameters on viscosities of coalwater mixture prepared with Erzurum-Aşkale lignite coal," Fuel Processing Technology, 87(9), hal. 821-827.

doi: 10.1016/j.fuproc.2006.05.004.

Hashimoto, N. (1999) "CWM: Its past, present and future," Coal Preparation, 21(1), hal. 3-22. doi: 10.1080/07349349908945605.

Li, P., Yang, D., Lou, H. dan Qiu, X. (2008) "Study on the stability of coal water slurry using dispersion-stability analyzer," Journal of Fuel Chemistry and Technology, 36(5), hal. 524529. doi: 10.1016/S1872-5813(08)60033-X.

Liao, J., Fei, Y., Marshall, M., Chaffee, A. L. dan Chang, L. (2016) "Hydrothermal dewatering of a Chinese lignite and properties of the solid products," Fuel, 180, hal. 473-480. doi: 10.1016/j.fuel.2016.04.027.

Liu, J., Wu, J., Zhu, J., Wang, Z., Zhou, J. dan Cen, K. (2016) "Removal of oxygen functional groups in lignite by hydrothermal dewatering: An experimental and DFT study," Fuel, 178, hal. 85-92. doi: 10.1016/j.fuel.2016.03.045.

Mishra, S. K. dan Kanungo, S. B. (2000) "Factors affecting the preparation of highly concentrated coal-water slurry (HCCWS)," Journal of Scientific \& Industrial Research, 59, hal. 765-790.

Mishra, S. K., Senapati, P. K. dan Panda, D. (2002) "Rheological behavior of coal-water slurry," Energy Sources, 24(2), hal. 159-167. doi: 10.1080/00908310252774471.

Nyashina, G. S., Kuznetsov, G. V. dan Strizhak, P. A. (2018) "Energy efficiency and environmental aspects of the combustion of coal-water slurries with and without petrochemicals," Journal of Cleaner Production, 172, hal. 1730-1738. doi: 10.1016/j.jclepro.2017.12.023.

Ongsirimongkol, U. dan Narasingha, M. H. (2012) "Effects of stabilizing agents on stability and rheological characteristics of the highly-loaded coal-water slurry," International Journal of Chemical Engineering and Applications, 3(1), hal. 49-52.
Pinchuk, V. A., Sharabura, T. A. dan Kuzmin, A. V. (2019) "The effect of water phase content in coal-water fuel on regularities of the fuel ignition and combustion," Fuel Processing Technology, 191, hal. 129-137. doi: 10.1016/j.fuproc.2019.04.011.

Routray, A., Senapati, P. K., Padhy, M., Das, D. dan Mohapatra, R. K. (2019) "Effect of mixture of a non-ionic and a cationic surfactant for preparation of stabilized high concentration coal water slurry," International Journal of Coal Preparation and Utilization, hal. 1-16. doi: 10.1080/19392699.2019.1674843.

Salomatov, V. V., Kuznetsov, G. V., Syrodoy, S. V. dan Gutareva, N. Y. (2016) "Ignition of coalwater fuel particles under the conditions of intense heat," Applied Thermal Engineering, 106, hal. 561-569.

doi: 10.1016/j.applthermaleng.2016.06.001.

Sato, Y., Kushiyama, S., Kondo, Y., Takagi, H., Maruyama, K. dan Yoshizawa, N. (2007) "Property of upgraded solid product from low rank coal by thermal reaction with solvent," Fuel Processing Technology, 88(4), hal. 333341. doi: 10.1016/j.fuproc.2005.02.002.

Sukardi dan Suryana, A. (1999) "Pengkajian cekungan batubara di daerah Bayung Lencir, Kabupaten Musi Banyuasin, Propinsi Sumatera Selatan," in Pemapan hasil lapangan DIK-S Batubara. DSM, hal. 7.1-7.10.

Turian, R. (2002) "Properties and rheology of coalwater mixtures using different coals," Fuel, 81(16), hal. 2019-2033. doi: 10.1016/S00162361(02)00149-7.

Ullah, H., Liu, G., Yousaf, B., Ali, M. U., Abbas, Q., Zhou, C. dan Rashid, A. (2018) "Hydrothermal dewatering of low-rank coals: Influence on the properties and combustion characteristics of the solid products," Energy, 158, hal. 11921203. doi: 10.1016/j.energy.2018.06.052.

Umar, D. F., Daulay, B., Usui, H. dan Komoda, Y. (2007) "Effect of coal upgrading on rheology of coal water mixture," Indonesian Mining Journal, 10(3), hal. 13-17.

Umar, D. F., Shimojo, M. dan Madiutomo, R. M. N. (2018) "Evaluation of combustion behaviour for Indonesian low-rank coals treated hydrothermally," Indonesian Mining Journal, 21(2), hal. 127-139. doi: 10.30556/imj.Vol21.No2.2018.919.

Valiullin, T. R., Vershinina, K. Y., Kuznetsov, G. V. dan Strizhak, P. A. (2020) "An experimental investigation into ignition and combustion of 
groups of slurry fuel droplets containing high concentrations of water," Fuel Processing Technology, 210, hal. 106553.

doi: 10.1016/j.fuproc.2020.106553.

Wu, J., Liu, J., Zhang, X., Wang, Z., Zhou, J. dan Cen, K. (2015) "Chemical and structural changes in XiMeng lignite and its carbon migration during hydrothermal dewatering," Fuel, 148, hal. 139-144. doi: 10.1016/j.fuel.2015.01.102.

Xiaochun, W., Guoguang, W. dan Gongyuan, W. (2004) "Additives of coal water slurry and its recent development," Coal Chemical Industry, (6), hal. 15-18.

Yu, Y., Liu, J., Wang, R., Zhou, J. dan Cen, K. (2012) "Effect of hydrothermal dewatering on the slurryability of brown coals," Energy Conversion and Management, 57, hal. 8-12. doi: 10.1016/j.enconman.2011.11.016.

Yu, Y., Liu, J. dan Cen, K. (2014) “Properties of coal water slurry prepared with the solid and liquid products of hydrothermal dewatering of brown coal," Industrial \& Engineering Chemistry Research, 53(11), hal. 4511-4517.

doi: 10.1021/ie5000592.

Yuchi, W., Li, B., Li, W. dan Chen, H. (2005) “Effects of Coal Characteristics on the Properties of Coal Water Slurry," Coal Preparation, 25(4), hal. 239-249. doi: 10.1080/07349340500444489.

Zhang, Y., Wu, J., Wang, Y., Miao, Z., Si, C., Shang, $X$. dan Zhang, N. (2016) "Effect of hydrothermal dewatering on the physicochemical structure and surface properties of Shengli lignite," Fuel, 164, hal. 128-133. doi: 10.1016/j.fuel.2015.09.055.

Zhu, J., Liu, J., Shen, W., Wu, J., Wang, R., Zhou, J. dan Cen, K. (2014) "Improving the slurrying ability of XiMeng brown coal by medium- to low-temperature thermal treatment," Fuel Processing Technology, 119, hal. 218-227. doi: 10.1016/j.fuproc.2013.11.010. 
